\title{
Did the German Model Survive the Labor Market Reforms?
}

\author{
Joachim Möller
}

Published online: 15 July 2015

(C) Institut für Arbeitsmarkt- und Berufsforschung 2015

\begin{abstract}
This paper discusses the specific features of the German model as a specific variety of capitalism that is distinct from the Anglo-Saxon model because it builds more on social security and social partnership. It argues that the German model has experienced increasing pressure due to growth in systemic unemployment since the mid-1970s. The situation worsened as a result of the financial distress experienced after re-unification. Therefore, although painful for some groups of workers, the labor market reforms implemented from 2003 to 2005 were necessary to keep the German model alive. I argue that a certain erosion of the German model resulting from less collective bargaining coverage, labor market segmentation and higher wage inequality has falsely been attributed to the reforms. Rather, these phenomena are caused by long-run trends that were already occurring in the 1990 s or even earlier.

The German economy successfully passed the stress test of the Great Recession and is exhibiting ongoing employment growth. Basic features of the German model such as long tenures for qualified prime-age workers or the dual training system remain essentially intact. Hence, the German model is not dead, but vitally alive. However, some prudent counter-measures need to be implemented to fight
\end{abstract}

The article is a completely revised and substantially extended version of Möller 2014a.

J. Möller $(\bowtie)$

Institute for Employment Research (IAB),

Regensburger Str. 104,

90478 Nuremberg, Germany

e-mail: joachim.moeller@wiwi.uni-regensburg.de

J. Möller

IZA, University of Regensburg,

Universitätsstraße 31,

93053 Regensburg, Germany against creeping erosion from segmentation and inequality. These should be taken with a sense of proportion in order to not jeopardize the great employment-related successes of the reform.

Keywords Labor market reforms · Systemic unemployment $\cdot$ Segmentation · Inequality

JEL-classification $\mathrm{J} 10 \cdot \mathrm{J} 28 \cdot \mathrm{J} 31 \cdot \mathrm{J} 50 \cdot \mathrm{P} 10$

\section{Hat das Modell Deutschland die Arbeitsmarktreformen überlebt?}

Zusammenfassung Der Aufsatz diskutiert entlang verschiedener Dimensionen die Kennzeichen des deutschen Modells als einer besonderen Spielart des Kapitalismus. Diese unterscheidet sich vom angelsächsischen Modell, da sie stärker auf soziale Absicherung und Sozialpartnerschaft setzt. Er argumentiert, dass das deutsche Modell aufgrund der seit Mitte der 1970er Jahre schubartig angewachsenen Sockelarbeitslosigkeit zunehmend unter Druck geraten ist. Die Situation verschlechterte sich noch aufgrund der finanziellen Belastungen durch die deutsche Wiedervereinigung. Obgleich schmerzhaft für bestimmte Arbeitnehmergruppen, waren die in den Jahren 2003 bis 2005 durchgeführten Arbeitsmarktreformen letztlich unvermeidlich, um einen Kollaps des Systems zu verhindern. Gewisse Erosionserscheinungen am deutschen Modell wie die rückläufige Tarifabdeckung, die zunehmende Segmentation des Arbeitsmarktes und die höhere Lohnungleichheit werden fälschlicherweise den Reformen zugeschrieben. Die empirischen Fakten belegen, dass diesen Phänomenen längerfristige Trends zugrunde liegen, die schon vor den Reformen in den 1990er Jahren oder sogar früher einsetzten. 
Nach den Reformen überstand die deutsche Wirtschaft den Stresstest der Großen Rezession erfolgreich und zeigte nachhaltiges Beschäftigungswachstum. Wesentliche Bestandteile des deutschen Modells wie die langen Betriebszugehörigkeiten von qualifizierten Facharbeiter/innen, das duale Ausbildungssystem, die starke Exportorientierung sowie eine solide finanzierte Sozialversicherung sind im Wesentlichen erhalten geblieben. Deswegen ist das deutsche Modell keineswegs abgewickelt, sondern im Kern weiterhin sehr lebendig. Eine gewisse Bedrohung ergibt sich aus den schleichenden Erosionserscheinungen durch wachsende Segmentation und Ungleichheit. Hierauf sollte mit ausgewogenen Gegenmaßnahmen reagiert werden, die jedoch nicht die Beschäftigungserfolge des bisherigen Reformprozesses wieder in Frage stellen sollten.

\section{Introduction}

As Sigurt Vitols shows, the notion of the "German" or "Rhine" model of capitalism appeared more than 100 years ago with various rather different definitions (Vitols 2006). Max Weber, Werner Sombart and others used this notion to describe the specific characteristics of the German economy in the early 20th century. Socialists like Hilferding used it to highlight specific forms of industrial cartelization and close relations between banks and large enterprises (Hilferding 1910). Several decades later, in the mid-1970s, the socialdemocratic chancellor Helmut Schmidt started his election campaign using the motto "Modell Deutschland" as a specific response to the structural challenges experienced after the deep supply shocks of the oil-price crisis that took place at that time.

Despite its fuzziness, the notion of the German model has played a central role in the debate on the varieties of capitalism since the early 1990s (Esping-Andersen 1990, Albert 1993; Streeck 1992, 1997; Hall and Soskice 2001a). The basic claim in the debate is that 'capitalism' or market societies may be organized in rather different forms. These differences include wage bargaining and other labor market institutions, the stance towards active labor market policy, the organization and generosity of the social security system, forms of cooperation between social partners or interest groups, educational systems and forms of economic specialization, among others. The traditional German model has been characterized along these dimensions in the literature.

Shortly after re-unification, some authors were already skeptical about the chances that the specific "German" variety of capitalism would survive in the face of financial strain and "globalization," i.e., under conditions of growing integration into the world economy, offshoring and high capital mobility (Streeck 1997). This skepticism was strengthened at the beginning of the millennium when the
German economy in general and German labor market in particular came under pressure. Was there an erosion of the fundamental features of the German model, culminating in the labor market reforms of 2003-2005 and Chancellor Gerhard Schröder's “Agenda 2010"? Did these developments mean that the German model had been abandoned? In the following, I will argue that - in order to adapt to new conditions in the European and world economy-the German economy and social system had to be transformed along several dimensions. Some of the core elements of the system were weakened and others were strengthened. Overall, the German variety of capitalism is still intact, although an increasing dualism might threaten the concept of a solidaristic society. Hence, this raises the question of how these tendencies can be counteracted without jeopardizing the indisputable economic successes and marked favorable labor market development of the country.

The remainder of this paper is organized as follows. In Sect. 2, I discuss the various features ascribed to the German model in the literature and suggest an eclectic approach to obtain a workable definition. Section 3 analyzes the longterm creeping threat to the German model of steadily growing unemployment and globalization. Section 4 addresses the Hartz reforms and the rationale behind the reform process. Section 5 describes the concepts and effects of the reform. The challenges to the German model are the subject of Sect. 6. Finally, Sect. 7 contains a discussion of the results and the conclusion.

\section{What constitutes the German model?}

\subsection{Corporatism: The German model as an in-between case}

In most classifications used in this context ${ }^{1}$, the German model appears as an intermediate case between the AngloSaxon type market economies on the one hand (deregulated, inegalitarian, neo-liberal) and Scandinavian-type societies on the other (coordinated at the national level, egalitarian, highly unionized). There is a grouping of types of welfare states corresponding to this classification. Esping-Andersen has stressed the notion of de-commodification as a distinguishing criterion ${ }^{2}$. In the cluster of Anglo-Saxon "liberal" states, one finds means-tested assistance, meager universal transfers and social insurance plans. "Entitlement rules are therefore strict and often associated with stigma; benefits are typically modest. In turn, the state encourages the mar-

\footnotetext{
${ }^{1}$ See, for instance, Thelen 2012, p. 144.

${ }^{2}$ In this context, de-commodification can be understood as the establishment of social institutions that are not governed by market processes.
} 
ket, either passively, by guaranteeing only a minimum, or actively, by subsidizing private welfare schemes" (EspingAndersen 1990, p. 111). According to the author, Germany belongs to the second cluster of corporativist welfare states, where " ... the granting of social rights was hardly ever seriously contested. What was predominant was the preservation of status differentials" (Esping-Andersen 1990, p. 111). On the one hand, private insurance plays only a minor role in this system and, on the other hand "... upholding status differences means that its redistributive effects are negligible" (Esping-Andersen 1990, p. 111) ${ }^{3}$. The third cluster described by Esping-Andersen is what he calls the "social democratic regime," traditionally implemented in the Scandinavian countries. In this system, "the principles of universalism and decommodifying social rights were extended to the new middle classes" (Esping-Andersen 1990, p. 111).

The theme of corporatism has also been examined by economists. Dating back to the late 1980s, the Calmfors/ Driffill debate stresses the relationship between the degree of centralization of wage bargaining and macroeconomic performance. It is argued that the best economic results are derived from either a completely decentralized system, like in the Anglo-Saxon countries, or a system allowing for wage bargaining at the aggregate level. As the authors put it, “... extremes work best" (Calmfors and Driffill 1988, p. 13). Germany, among others, is seen as being ".. between these polar cases, with wage setting mainly at the industry level" (Calmfors 1993, p. 161).

There is a broad literature on various aspects of corporatism that goes back at least to the famous book of Bruno, Sachs (1985). Among others, Layard et al. (1991) use an index of corporatism to analyze its effects on macroeconomic performance in a cross-section of countries ${ }^{4}$. Kenworthy (2002) emphasizes that wage coordination is only one aspect of how corporatism affects labor market outcomes, with the other being union participation in decisionmaking. The author's empirical analysis suggests that the effect of wage coordination on unemployment was strong in the 1980s but disappeared in the 1990s. However, Kenworthy (2002) considers a second channel-i.e., the influence of unions on policy making - as still being effective. Visser (1998) provides evidence on the positive effect of corporatism on labor market outcomes in the Netherlands. He argues that in addition to the influencing wage determination, corporatism strongly affects negotiated working hour flexibility.

\footnotetext{
${ }^{3}$ Moreover, the author sees a strong commitment to the preservation of traditional family patterns in this regime.

${ }^{4}$ In this context, the use of simple corporatism indicators in a crosssection has been criticized by Burda 1997, among others.
}

2.2 Egalitarism, industrial relations and the productive model

Traditionally, a constituent feature of the German model was solidarity. The slogan of Ludwig Erhard, minster of economic affairs and chancellor during the period of the German Wirtschaftswunder in the 1950s and 1960s, was "Prosperity for All," which was by no means an empty phrase. For almost 5 decades after World War II, the rising economic tide was lifting all boats, both large and small. Until the mid-1990s, this was accompanied by wage compression. According to indicators of earnings inequality, Germany was traditionally closer to the Scandinavian than Anglo-Saxon countries. Supported by high unionization and a solidaristic wage policy, the system tended to be egalitarian.

A highly developed structure of industrial relations can be seen as a complement to this. Pointing to the seminal work of Michel Albert, Boyer writes that, "... the German form of highly specific industrial relations has been perceived as a key component in the success of a productive model based on diversified quality production" (Boyer 2006, p. 135). Crucial for the German strategy is the fact that wage policy is directed towards stimulating high-productivity growth. The so-called productivity whip of a tough wage policy should ensure that firms with low productivity leave the market and release their workforces, allowing them to participate in more productive markets. Over the post-war decades, this specific institutional configuration led to the high competitiveness and striking export successes of the German economy. Hence, the model was stable and widely accepted.

Streeck describes the formation of the German productive model as a response to new challenges as follows:

In Germany(...) the co-existence of strong unions continuing to guarantee high wages and low wage dispersion, with a central bank increasingly following a monetarist agenda, forced a re-structuring of the production apparatus toward what was later called 'diversified quality production': a unique multiple palette of demanding and qualitatively outstanding products being designed for world market niches that could justify the high and low differentiated wages of their producers through the realization of high prices in international competition (Streeck 2005, p. 9, translation by the author).

What the author describes as the "monetarist agenda" is German monetary policy's characteristic aversion to inflation. Streeck argues that the described development has especially favored strong medium-size manufacturing firms, which are often denoted as hidden champions, i.e., world-market leaders in their specific field of specialization. 
Whether the fundamentals in the system of wage negotiation that led to the high level and low dispersion of earnings were the pivotal point for the formation of German specialization in specific world-market niches in the manufacturing sector is debatable. The industrial tradition, dual training system, infrastructure and existence of efficient networks of industries and technical universities are complementary factors. In addition, the relatively generous social security system has also traditionally played a role in reducing the risks of fluctuating world markets for the specialized workforce.

\subsection{What constitutes the German model?}

There are varying definitions of the German model in the literature. They differ with respect to their emphasis on different features and structural elements of the system. Wolfgang Streek defines the German model as "...(an) institutionalized high wage economy combining high competitiveness in world markets with strong social cohesion and, in particular, low levels of inequality along a variety of dimensions" (Streeck 1995, p. 2), whereas Albert (1993) emphasizes the highly specific industrial relations in combination with a productive model based on diversified quality production. Ten years later, Hall and Soskice (2001a) describe the German type of market economy as "....an emblematic example of a coordinated capitalism, which should be juxtaposed to the liberal market capitalism typical of the American configuration" (Boyer 2006), p. 135). Similarly, Freeman (2001) characterizes what he calls the "Rhineland Model".

The fuzziness of these definitions from the perspectives of different disciplines is not surprising. In a recent article, Kathleen Thelen criticizes the one-dimensional classification of socio-economic systems along a continuum, regardless of whether it is called "corporatism" or "coordination." The varieties of capitalism can be described along several political, institutional, historical, structural and behavioral dimensions. Thelen stresses the coalitional foundations on which political-economic institutions rest: "A coalitional approach reveals that institutions that in the past supported the more egalitarian varieties of capitalism survive best not when they stably reproduce the politics and patterns of the Golden Era but rather when they are reconfigured -in both form and function- on the basis of significantly new political support coalitions" (Thelen 2012). The author argues that there are "... no serious disagreements about which core institutional arenas analysts should be studying ...: industrial relations institutions, financial arrangements, corporate governance, social policy structures, and institutions for education and training" (Thelen 2012, p. 2). This encourages an eclectic approach to defining the traditional German model.

Table 1 shows the most important features of the German model. The central pillars of the system are effec-
Table 1 Dimensions characterizing the German model

\begin{tabular}{|c|c|}
\hline Dimension & Characteristic of the German model \\
\hline Governance & $\begin{array}{l}\text { Coordinated market economy, intermediate corpo- } \\
\text { ratism, moderate industrial policy }\end{array}$ \\
\hline $\begin{array}{l}\text { Social } \\
\text { security }\end{array}$ & $\begin{array}{l}\text { Bismarck type: mainly financed through wage- } \\
\text { related contributions, relatively generous transfer } \\
\text { system (intermediate de-commodification) }\end{array}$ \\
\hline $\begin{array}{l}\text { Labor } \\
\text { relations }\end{array}$ & $\begin{array}{l}\text { Social partnership through work councils, co- } \\
\text { determination, low fluctuation (long tenures), job } \\
\text { protection and other regulations }\end{array}$ \\
\hline $\begin{array}{l}\text { Labor market } \\
\text { policy }\end{array}$ & $\begin{array}{l}\text { Strong role of active labor market policy, buffering } \\
\text { of labor market shocks through short-term working } \\
\text { allowances and other instruments }\end{array}$ \\
\hline Education & $\begin{array}{l}\text { Dual system of vocational training and firm invest- } \\
\text { ment in general and specific in-house training }\end{array}$ \\
\hline $\begin{array}{l}\text { Wage } \\
\text { formation }\end{array}$ & $\begin{array}{l}\text { Collective bargaining at the intermediate (sectoral, } \\
\text { regional) level; orientation toward aggregate pro- } \\
\text { ductivity; collective bargaining autonomy enshrined } \\
\text { in German Basic Constitutional Law }\end{array}$ \\
\hline $\begin{array}{l}\text { Wage } \\
\text { dispersion }\end{array}$ & Low wage dispersion; egalitarian policy stance \\
\hline $\begin{array}{l}\text { Economic } \\
\text { structure }\end{array}$ & $\begin{array}{l}\text { Strong role of export-oriented manufacturing, } \\
\text { diversified quality production in niches }\end{array}$ \\
\hline Finance & $\begin{array}{l}\text { House-bank system, "patient capital," under-devel- } \\
\text { oped venture capital }\end{array}$ \\
\hline Infrastructure & $\begin{array}{l}\text { Efficient transport and logistics, reliable legal and } \\
\text { administrative systems }\end{array}$ \\
\hline
\end{tabular}

tively corporist structures and a strong social partnership, a relatively generous social security system that is at the core of Bismarck-type social security (status-oriented and mainly financed by social contributions). The economy is geared toward export-oriented manufacturing, benefiting from a well-developed system of dual vocational training and a well-educated workforce. Fluctuations are relatively minor. Wage bargaining takes place at the intermediate (sectoral, regional) level; however, through wage-leadership (Lohnführerschaft), the outcomes at the aggregate level are rather similar. Although union coverage takes place only at the intermediate level, the strong role of unions in the bargaining process leads to a solidaristic wage policy (low wage dispersion). Federal institutions are engaged in active labor market policy and the buffering of labor market shocks through short-term working allowances and other instruments. The financing of companies depends on a house-bank system. Finally, the German system relies on a solid infrastructure, especially with respect to transport and logistics but also in relation to the legal system.

It is important to regard these various dimensions not as isolated, but rather as strongly interrelated. Hall and Soskice (2001b, p. 17) coined the notion of institutional complementarities, i.e., the presence of one institution increases the efficiency of another. To illustrate some of these interrelationships, consider the following examples.

(i) Robert Boyer emphasizes the "strong complementarity between product strategy and human resource manage- 
ment" (Boyer 2006, p. 137). An important characteristic of labor relations in the German model is the priority of withinfirm flexibility relative to external flexibility ${ }^{5}$. The preference for retaining a qualified workforce even during severe recessions stems from the high importance of firm-specific capital, which originates from the needs of export-oriented diversified quality production. This product strategy requires the flexible use of equipment by highly skilled workers that is crucial for specialized firms facing highly volatile product demand in the world market. Labor hoarding during periods of slack demand is a suitable instrument, especially if this behavior is publically supported through generous short-term working allowances. However, labor hoarding in combination with massive reductions in working hours and temporary earnings moderation requires mechanisms of social partnership and trust. Work councils serve as intermediaries to arbitrate between the conflicting interests of management and workers. Hence, this institution plays a key role in organizing within-firm flexibility through various measures to stabilize employment. Moreover, a social partnership is also required in regard to fostering training measures and high workplace security standards. Traditionally, the system of well-functioning labor relations in Germany is especially developed in the manufacturing sector, where there are high levels of unionization and collective bargaining coverage.

(ii) The dual vocational training system fits well with diversified quality production. The dual system combines the acquisition of both theoretical and practical knowledge. Recent graduates sign a contract with a firm. They receive practical training at the firm and 1 day per week of theoretical training at a public vocational school. An important aspect of this system is that it offers corresponding training resources such as the working time of experienced workers who are able to transfer firm-specific and general skills to their apprentices. Because the curricula within professions are codified, a worker who completed an apprenticeship in a specific field can be expected to possess the standard skills that are typical of related professions. Hence, a corresponding certificate in a certain profession serves as a signifier of a bundle of skills and competences.

(iii) As another salient feature of the traditional German model, low wage dispersion was supported by the fact that skill differentials were generally compressed when Fordian production was dominating manufacturing industries. Under conditions of mass production with a high degree of division of labor, low-skilled workers were relatively productive and were consequently in high demand.

\footnotetext{
${ }^{5}$ This point has already been stressed by the profound analysis of the differences between the German and U.S. systems by Abraham and Houseman (1995).
}

(iv) The social security network has developed since the time of Bismarck in the late 19th century. The system is financed through social contributions as a percentage of gross earnings. Traditionally, the unemployment insurance system was comparatively generous in terms of the replacement ratio as well as the length of the entitlement period for insurance benefits. Generous unemployment insurance can be seen as complementary to an export-oriented volatile economy in which workers are highly specialized. The system fits the needs of a workforce dominated by professional workers (Facharbeiter) with long tenures and a relatively low risk of experiencing frequent spells of unemployment rather than a workforce in which stable work biographies are the exception and not the rule.

\section{The German model under pressure}

\subsection{Globalization and the fall of the iron curtain}

In the mid-1990s, in his famous article, Wolfgang Streeck asked with some skepticism whether the German model, as a relatively egalitarian high-wage economy, could survive in the face of "globalization", i.e., under conditions of growing integration into the world economy, offshoring and high capital mobility (Streeck 1997). This is akin to what Thelen and van Wijnbergen call the neoliberal offensive position, i.e., the thesis that "...globalization pushes all countries toward neoliberalism and deregulation, encouraging firms to lower labor cost and increase labor market flexibility while undermining the power of unions to prevent these..." (Thelen and van Wijnbergen 2003, p. 859).

It should be stressed that in the tradition of Bismarck, the financing of the social security net is strongly tied to the wage bill. There is therefore a broad consensus that the traditional German model presupposes a sufficiently high share of active workers. Consequently, elevated unemployment puts the system under pressure. According to (Streeck 2005, p. 9), the organized solidarity within the system underwent a tensile test in the late 1990s, when an additional surge in internationalization generated competitive pressure on German enterprises. This also increasingly began to affect the formerly very successful niche producers. With steadily increasing systemic unemployment since the mid-1970s, the foundations of the model were undermined.

Most authors agree that perhaps these problems were not caused but rather aggravated by the dramatic economic consequences of German re-unification. West Germany absorbed an economy with a non-competitive industrial base and a desolate public infrastructure. From the early 1990s onwards, the high financial burden of German reunification became an additional challenge for public and private budgets. As a result, the German economy was 
plagued by low growth and job creation rates. Furthermore, the deep structural crisis of the East German economy led to extremely high unemployment rates in almost all regions of the new Länder. Management and labor market institutions were not sufficiently flexible to cope with the huge burden of adjustment after re-unification. Within the monetary union with West Germany, the post-socialist East German economy, characterized by poor infrastructure and obsolete equipment, was exposed to the world market from 1 day to the other without having the possibility to devaluate its currency to regain competitiveness.

In the late 1990s, the German economy felt some additional negative effects immediately after the introduction of the Euro. Capital flows were re-directed to formerly high-interest countries within the Euro zone, which was detrimental to home investment. After profiting in the first years after the opening of the borders to the East, West German industry ran into problems. Germany appeared to be increasingly sclerotic, unable to cope with the challenges of the structural changes demanded by the new period of globalization. As a consequence, the German economy entered a critical phase. In 1999, the Economist mocked Germany as the "sick man in Europe." It was doubtful whether the system was sustainable.

In a critical re-appraisal of the Calmfors/Driffill debate on the corporatism and economic performance of the early 1990s, Driffill (2006) corroborates the basic results of early research. In case of Germany, the author calls into question whether the country has maintained its original position. "Recently, however, there have been moves towards more flexible lower-level bargaining procedures and some authors argue that the erosion of the 'German model' may have already started" (Driffill 2006, p. 746). The author refers to two manifestations of greater flexibility: (i) the emergence of company-level alliances between employers and employees to secure employment and competitiveness and (ii) the spread of contingent pay arrangements.

Indeed, the "Alliance for Employment" (Bündnis für Arbeit), which was politically initiated under chancellor Schröder in the late 1990s, tried to re-activate the forces of corporatism. The initiative, however, turned out to be a failure. It was unable to effectively generate momentum to reduce joblessness. Hence, the political debate in the first half of the first decade of the new century centered on poor labor market performance. Colin Crouch, for instance, stated that, "the decline in Germany's capacity to provide employment for its population has become one of the most discussed economic questions on the turn of the twentieth and twenty-first centuries" (Crouch 2006), p. 159). Similarly, Lane Kenworthy noted that, "Germany's principal economic problem (is) an inadequate and stagnant rate of employment" (Kenworthy 2006). Colin Crouch describes the policy response as follows: "Rather than seeking to increase demand for labor, social democratic and tradeunion policy makers in Germany sought to reduce its supply" (Crouch 2006, p. 165). It became increasingly obvious, however, that neither the strategy of early retirement nor the reduction of working hours led to lower unemployment or an increase in the wage bill.

\subsection{Structural problems}

According to some observers, the structure of the economy was at the heart of the poor employment record. Rather evidently, Germany did not manage to boost new job creation in some labor-intensive branches of the service sector, especially eating \& drinking, care facilities and retail trade. In a comparison between Germany and the U.S., Richard Freeman and Ronald Schettkat show that a large proportion of the marked differences in employment rates stems from differences in these low-wage services (Freeman and Schettkat 2001). "Mediocre employment growth in these three service sectors is thus key to understanding Germany's employment woes" (Kenworthy 2006, p. 42). In an early study, Burda, Sachs (1987) analyze the relatively poor employment growth in the service sector. They find that “... the data are highly consistent with the hypothesis that wage rigidity in services - due to unionization, minimum wage provisions or overly generous unemployment benefits - has obstructed rapid labor-intensive growth service activities and can help to explain the continuing rise in the overall level of German unemployment" (Burda and Sachs 1988, p. 560). This conclusion is somewhat at odds with a later analysis, according to which wage levels were not the primary cause of the discrepancies between Germany and the U.S., because especially female workers in these sectors receive roughly comparable low wages in both countries (see Glyn et al. 2007) ${ }^{6}$.

The relative strength of the manufacturing sector as a constituting element of the German model was seen as a disadvantage rather than an advantage. Barry Eichengreen reflects on Hans-Werner Sinn's argument that Germany is becoming a bazaar economy ${ }^{7}$. He argues that the country "... is losing its manufacturing prowess" and that "... expensive German labor cannot compete with equally skilled but immensely less expensive workers in the east" (Eichengreen 2007, p. 1). The author argues for labor mar-

\footnotetext{
${ }^{6}$ A possible explanation for the poor development of services might be that product market regulation has played a role in the German context. Germany's product markets are among the most regulated in the OECD. In a theoretical model, Blanchard and Giavazzi (2003) show interdependencies between product and labor market regulations. There might be reinforcement and mitigation effects with an ambiguous influence of institutional settings. I am grateful to Michael Burda for pointing me to this aspect.

${ }^{7}$ For more details, see Möller (2014a).
} 
ket reforms in order to obtain more wage flexibility. In his view, it is necessary to restructure“... an overly generous welfare state so that it no longer saps the incentive to work at rates that firms can afford" (Eichengreen 2007, p. 2). Pointing to the successful restructuring of the British economy, the author sees a fundamental misperception in the German case because "... prosperity continues to be archaically associated with manufacturing..." (Eichengreen 2007, p. 3). It should be recalled that this position was taken before the financial crisis.

Colin Crouch clearly takes a differentiated view. He stresses the huge structural differences between the regions within a country: "In Germany and the UK alike, some of the most prosperous regions (Hamburg, London) have particularly low levels of manufacturing employment. On the other hand, the two South German Länder ... continue to be highly prosperous industrial regions with relatively high employment" (Crouch 2006, p. 177). Quite evidently, Germany seems to have a comparative advantage in the manufacturing sector. Therefore, Crouch asks about the extent to which Germany would be well advised to leave its manufacturing path.

In the aftermath of the financial crisis in the U.S. and the Great Recession, the view on the adequate size of the manufacturing sector has changed once again. Today, it is widely accepted that the German economy did rather well in recent years and was even seen as a growth engine within Europe, not despite but because of its "hypertrophic" manufacturing sector. A debate on re-industrialization recently started taking place even in the U.S. (e.g., Sperling 2012; see Möller $2014 \mathrm{c}$ for more details).

\section{The Hartz reforms}

\subsection{Rationale behind the reforms}

In retrospect, the foundations of the traditional German model of the Wirtschaftswunder have been eroding since the mid-seventies. At that time, mass unemployment became a menacing phenomenon. The striking ratchet effect in the unemployment figures that first appeared after the first oil price crisis led to a steady increase in systemic unemployment. In other words, after each recession, the hard core of unemployment was substantially higher than before. This can be described as a result of significant hysteresis effects due to, for instance, the depreciation of human capital through periods of long-term unemployment. Fatally, these mechanisms were reinforced by the relatively generous unemployment insurance system. Hence, the favorable elements of the traditional system that served as a buffer against demand shocks now achieved the opposite of the intended effect.
Furthermore, the structure of labor demand underwent a deep structural transformation. In the 1980s, the nature of technical progress and work place organization began to change. Low-skilled workers in particular were hurt by skill-biased technical progress resulting from computerization and other developments. Unions tried to fight against these fundamental forces by bargaining for a fixed component in wage increases (Sockelbeträge) in order to allow the lowest income groups to profit more than proportionally from economic development. However, this strategy was increasingly undermined by growing unemployment among low-skilled workers, which became a severe problem starting in the late 1980s.

In the first years of the new century, the situation that developed called for drastic reforms to secure basic social attainments. The result was a courageous political program ("Agenda 2010"), which Michael Burda called the "teutonic turnaround." In his programmatic speech from March of 2003, Chancellor Schröder argued: "If Germany refrains from modernizing its labor market institutions, then it will be modernized by the brute forces of the global markets, leaving barely enough room for a social protection net" (Deutscher Bundestag (2003, p. 2481), translation by the author). This can be seen as the expression of a widely shared sentiment that far-reaching reforms were necessary to keep the basic functioning of social security institutions alive. It might be argued, however, that the deep structural changes that came along with the reforms sacrificed basic elements of the German model. Hence, the controversial question is whether the reforms have thrown the baby out with the bathwater.

\subsection{The reform agenda}

The key elements of "Agenda 2010" aimed to reform labor market institutions. The so-called Hartz reforms, which represented the core of the Agenda, were implemented in different steps between 2003 and 2005. In addition to improving the effectiveness and efficiency of the Federal Employment Services, the fundamental concept to improve the functioning of the labor market and reduce unemployment can be characterized as "supporting and demanding." In other words, the reforms adopted a "carrot and stick" approach. On the "carrot" side, several instruments aimed to facilitate the integration of the unemployed, such as support for training measures, wage subsidies and improved conditions to place workers in new jobs. Concrete elements on the "stick" side include the - albeit moderate-weakening of job protection standards, the reduction of the maximum entitlement period for unemployment insurance benefits, the tightening of job acceptance regulations for the unemployed as well as the de-regulation of temporary work agencies. Perhaps the most substantial change, however, was the merger between unemployment assistance and welfare ("Hartz IV"). The 
implication of this change is that, after receiving unemployment insurance for 12 months, workers typically fall back into the basic welfare system. The former unemployment assistance system (Arbeitslosenhilfe) was related to previous earnings. Basic welfare, however, provides lump-sum, means-tested benefits only. Compared to the pre-reform situation, this meant a substantial deterioration in the positions of workers. Three important aspects have to be mentioned in this context. First, the social security system was traditionally status-oriented. The new institutional system, however, implies the possibility of a deep fall in social status after only 1 year of unemployment. This represented a credible threat. Second, compared to the pre-reform situation, the position of long-term unemployment recipients was significantly weaker. Third, the criteria under which workers could reject a job offer became stricter.

Taken together, these three elements of the reform placed strong pressure on the unemployed to find a new job quickly. Not surprisingly, this pressure led to changes in behavior. In particular, effects on the reservation wage of the unemployed, job search intensity and willingness of job seekers to make concessions could be expected. Moreover, the bargaining power of workers was also generally affected by these profound changes in the institutional environment.

A further element of the reform was the re-definition of the criteria for persons available to work in the labor market. Welfare recipients were considered to be available to work if they were able to work for at least $3 \mathrm{~h}$ a day. As a perhaps unintended by-product of this change, registered unemployment increased by approximately 0.5 million. This was one of the reasons that officially counted unemployment peaked at more than 5 million immediately after the reform.

\section{Reform effects}

\subsection{General effects}

The German labor market reforms of 2003 to 2005 were a drastic and painful but ultimately effective cure. Although not all parts of the reforms were well designed ${ }^{8}$, strong positive labor market effects were rapidly visible. Supported by a favorable external economic environment, the German economy experienced an extraordinary boom period in the 3 years following the reform. Between 2004:Q4 and 2008:Q2, real production growth was $9.4 \%$ in the aggregate economy

\footnotetext{
${ }^{8}$ For example, the concept of the so-called Personal Service Agencies (Personal-Service-Agenturen, PSA) was not properly thought through and turned out to be a relatively expensive and inefficient instrument in practice. The idea was that public employment agencies should engage in the temporary hiring-out of otherwise unemployed workers. In situations of slack labor demand, the PSAs should organize suitable training measures for the unemployed.
}

and $18.8 \%$ in manufacturing. From 2005 until the eve of the Great Recession at the end of 2008, unemployment fell from its peak level of more than 5 million to less than 3 million. Furthermore, the disastrous trend in systemic unemployment was reversed: For the first time since the 1960s, the unemployment rate at the beginning of the economic downturn (2008:Q3) was lower than at the beginning of the previous recession. Moreover, as shown by Fahr and Sunde (2009), Möller (2010), Klinger and Rothe (2012), or, more recently, Stops (2015), a marked increase of the efficiency parameter in the matching function (or an inward-shift of the Beveridge curve) indicated the improved functioning of the labor market due to behavioral and institutional effects as well as better performance of labor services.

The turnaround of systemic unemployment is documented in Fig. 1. The figure shows the evolution of unemployment in West Germany since the 1950s. The arrows connect the troughs of the unemployment series. As seen, the recession in the sixties did not lead to an increase in systemic unemployment, i.e., the troughs before and after the recession were at about the same levels. With the OPEC I crisis of the mid-1970s, the situation changed markedly. Since then, the level of unemployment lows increased from recession to recession, indicating the existence of hysteresis effects (see Blanchard and Summers 1987). In the postreform period after 2005, the upward trend dating back to the early seventies was reversed. Simultaneously, long-term unemployment decreased markedly.

The decrease in the unemployment rate is mirrored by an increase in employment. The end of the reform period in 2005 coincidences with a noticeable increase in employment eligible for social contributions (see Fig. 2). Note that before the reforms, the employment trend was especially negative in East Germany. Since 2005, the upward trend in the number of workers contributing to social security has more or less moved in parallel in both parts of the country. This positive trend was supported by the widespread abolition of generous early retirement options. As a result, the employment rates of older workers increased sharply.

Taken together, the evidence strongly corroborates the view that the labor market reforms led to a significant improvement in the performance in of the German labor market.

\subsection{Specific effects of reform on labor market behavior}

As a matter of fact, the wage increases observed in the aftermath of the reform were rather moderate and workers were more likely to accept unfavorable job conditions ${ }^{9}$. Figure 3 indicates changes in the behavior of applicants as

\footnotetext{
${ }^{9}$ As shown by Dustmann et al. 2014, there was an increase in the labor supply, especially at the lowest quantiles of the wage distribution. This
} 
Fig. 1 Long-run development of the German unemployment rate (as a percentage of the civil labor force, 1950-2014). (Data Source: German Federal Employment Agency; Arbeitsmarktberichterstattung)

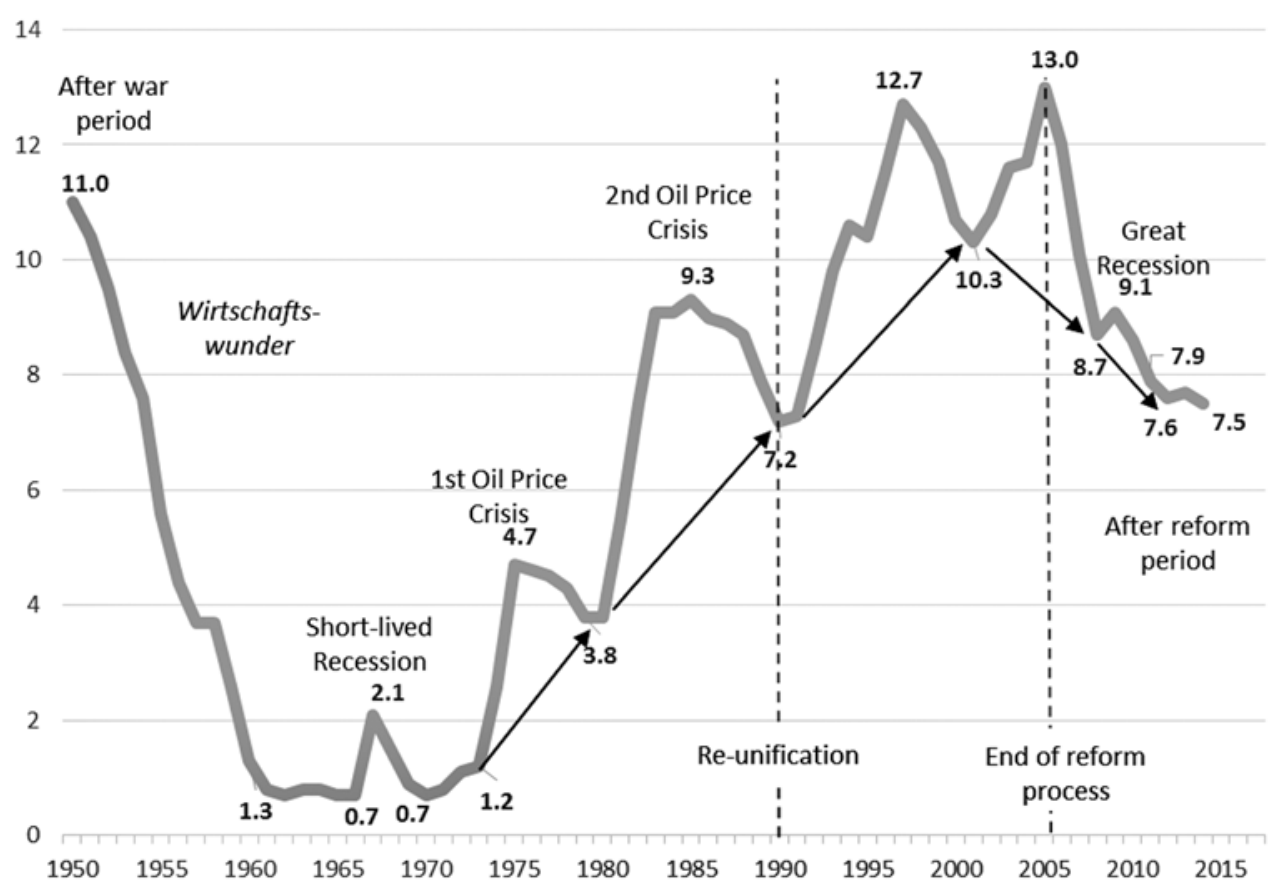

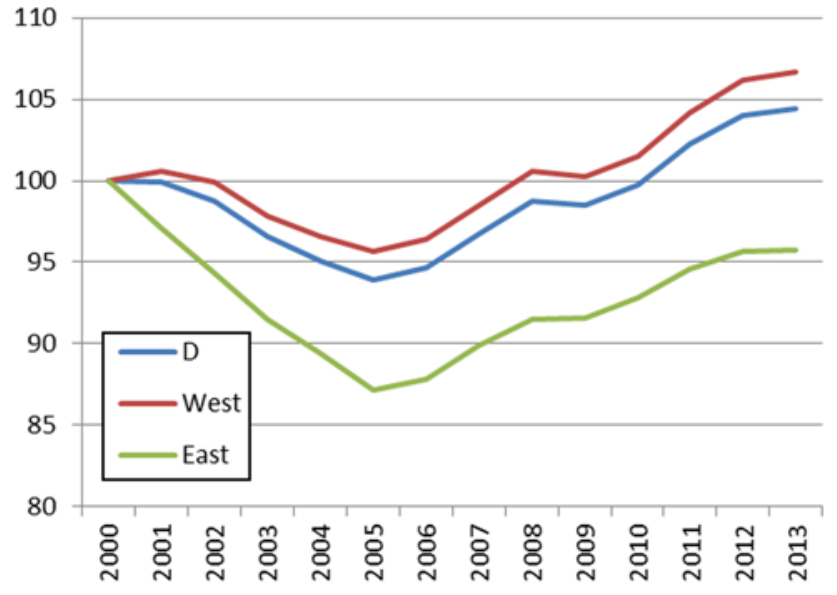

Fig. 2 Index of employment eligible to social contributions $(2000=100)$. (Source: German Federal Employment Agency; Arbeitsmarktberichterstattung)

perceived by employers. It turns out that in the post-reform years of 2005 and 2006, the overall willingness to engage in low-skilled tasks and accept lower wages or unfavorable working conditions increased significantly. These changes were especially strong immediately after the reforms were implemented in 2005. As shown in Fig. 4, the changes in the behavior of the incumbent workforce are at least as strong as the effects on job seekers. Employers perceived remarkably higher effort, more flexibility (for example, in the willingness to accept varying working hours) and acceptance

could have feedback effects on the evolution of wage moderation. Theoretically, this would also foster the employment at higher quantiles.

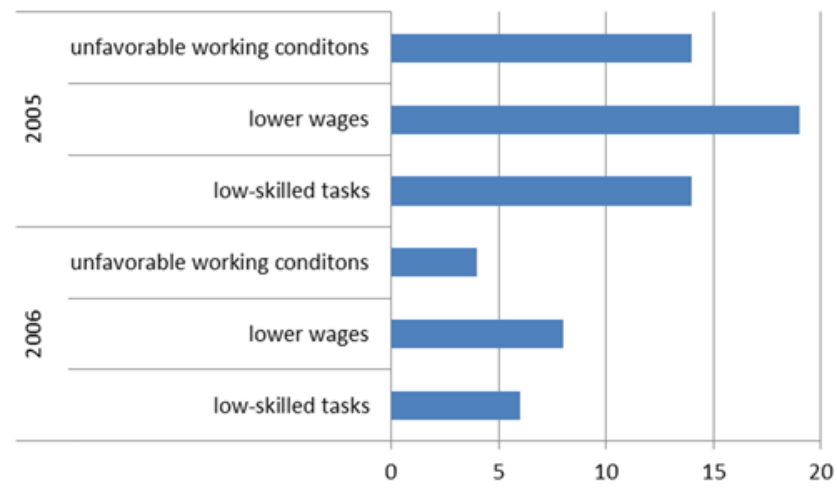

Fig. 3 Change in the willingness of jobseekers to accept unfavorable job characteristics (compared to the previous year). (Note: The bars indicate the difference between the share of firms' answers indicating a perceived increase or decrease, source: IAB Vacancy Survey)

of lower wages, albeit to a much lesser extent. Again, these effects were especially strong in 2005 , immediately after the reforms were implemented.

\subsection{Germany during the Great Recession}

The response of the labor market to the Great Recession can be seen as a first litmus test of whether the resilience mechanisms of the German model would survive the reforms. The degree of cushioning of employment in face of the extraordinarily sharp decline in external demand has been described as a miracle (for an explanation, see Möller (2010) or Burda and Hunt (2011)). As an export-oriented economy, the country was hit harder than other advanced countries by the 


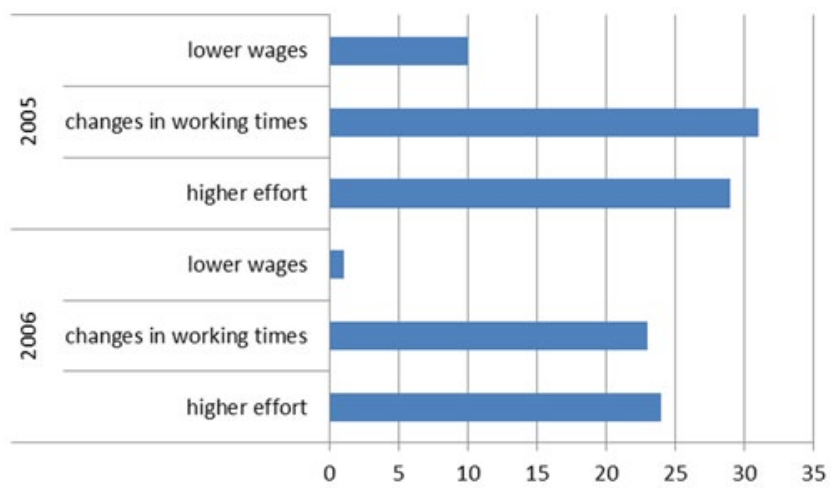

Fig. 4 Change in the willingness of the incumbent workforce to accept unfavorable job characteristics (compared to the previous year). (Note: The bars indicate the difference between the share of firms' answers indicating a perceived increase or decrease. source: IAB Vacancy Survey)

collapse of orders for exporters. Relative to trend growth, German GDP decreased by approximately 6.5\%. Despite this huge shock, the unemployment rate remained relatively stable. An unprecedented level of within-firm flexibility was the main explanation for this. First, it was the flexible response of working hours that led firms to keep their workforces stable. Through subsidies from the Federal Employment Agency (the so-called Kurzarbeitergeld), the financial burdens on firms and workers were held down. Because the crisis was perceived as a short-lived demand crisis by firms, labor hoarding turned out to be a reasonable strategy. An intact social partnership was a main pre-requisite to manage this high within-firm flexibility. For example, work councils played a major role in communicating the various measures (such as short-term work schemes and the so-called working time accounts) implemented to maintain stable employment. It was in the interest of workers to keep their jobs because of the threat of falling from unemployment insurance payments into means-tested social assistance after only 1 year of unemployment. Since mass layoffs were not unusual in earlier recessions and, if anything, employment protection had weakened in the last decade, one can argue that employment protection regulations were not the main reason for firms to keep their workforces stable. It is much more plausible that under the given circumstances, labor hoarding was voluntary on side of the firms.

The behavior during the Great Recession shows that the basic mechanisms of the German model evidently remained quite intact. The crisis was a confirmation of a healthy social partnership. Within-firm flexibility proved to be extremely effective in absorbing the enormous shock to GDP. The support of the Federal Labor Services' labor market policy helped confine the financial consequences of labor hoarding. Moreover, the strategy of retaining their qualified workforces paid off for firms. When the recovery gained momentum, firms were ready to respond very quickly to expand production.
After 2005, the strategy of diversified quality production turned out to be very successful. German firms could expand their market shares not only vis-à-vis their traditional trading partners but also in emerging markets. This can partly be explained by their provision of right mix of products that have been in high demand in recent years (machine tools, automobiles, chemical products). Hence, the traditional strength of the German economy in core manufacturing industries was favorable.

Although the labor market reforms came at some significant costs for large groups of workers, it seems that some basic ingredients of Agenda 2010 have not destroyed but rather strengthened the German variety of capitalism. They clearly helped overcome the most dangerous threats to the foundations of the German model, i.e., the increase in systemic unemployment and the loss of competitiveness in export markets.

\section{Challenges to the German model}

\subsection{Long-run trends and Hartz reforms}

In this context, perhaps the most important long-run trends in the labor market are (i) wage moderation, (ii) increasing wage dispersion and segmentation and (iii) declining union coverage. All these trends started long before the Hartz process was initiated. Rather than being caused by Agenda 2010, they are related to factors such as technical progress, the re-organization of industrial production in an increasingly integrated world economy, and, finally, to the fall of the iron curtain. There is no doubt that these factors caused deep structural changes in the German economy. With respect to the fall of the iron curtain, at least three channels must be mentioned. First, the opening to the East meant the emergence of low-wage countries like Hungary, Poland or the Czech Republic as direct neighbors of the German economy. The threat of the re-location of production sites substantially weakened the bargaining positions of workers and their unions. Second, the market potential of the German economy increased considerably. Third, the re-structuring process after re-unification-especially the collapse of manufacturing industries in East Germany-weakened overall union coverage in Germany.

Figure 5 shows the decline in the coverage of sectoral collective bargaining agreements (Flächentarifverträge) in West and East Germany. In the new Länder, coverage after re-unification was lower than in the West. Since then, the share of workers working under a general collective bargaining agreement has fallen at approximately equal rates in both parts of the country. As a result, in recent years, coverage of sectoral collective bargaining agreements has only been slightly above one-third in the East and one-half in 


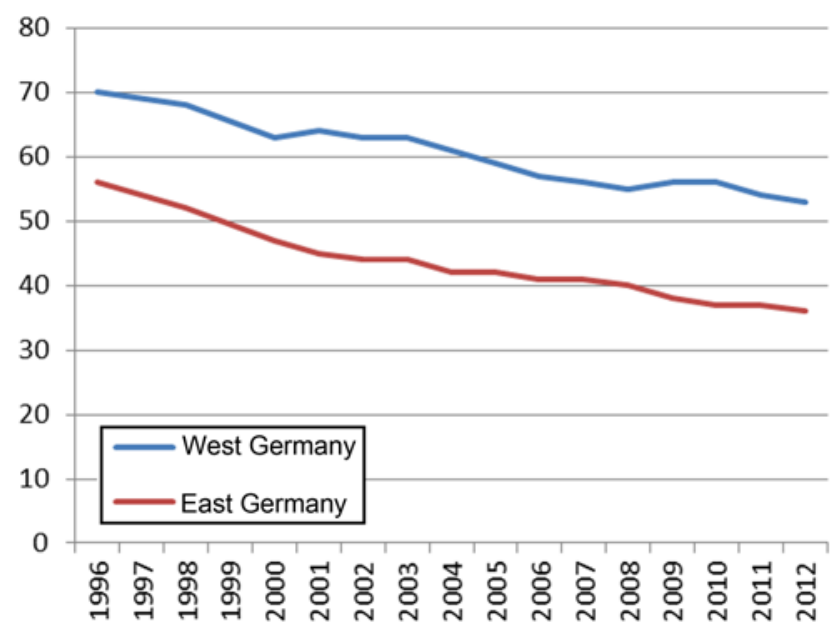

Fig. 5 Coverage of collective bargaining agreements (as a percentage of workers). (Source: IAB)

the West. As seen in the figure, the period of labor market reforms had neither a markedly negative nor positive influence on these trends.

It is often argued that the importance of collective bargaining is de facto higher than what is reflected in these figures because in many cases, firms that do not fall under a collective bargaining scheme (i.e., are not part of an employers' association) report that collective bargaining agreements orient their wage policies (Schnabel 2005). Additionally, in 2012, firm-level collective agreements (Firmentarifverträge) were reached by $7 \%$ of firms in the West and $12 \%$ in the East (see IAB 2014). Overall, however, the coverage of sectoral collective bargaining agreements is declining. This development, which is partly due to structural change in the economy, can be seen as an erosion of a key element of the German model.

\subsection{The evolution of wage inequality}

Several authors have addressed the fact that wage inequality has risen substantially in Germany over the last 2 or 3 decades (see, for instance, Dustmann et al. (2009) and Card et al. (2013)). Figure 6 shows indicators of wage inequality for prime-age full-time workers in West Germany in the period from 1984 to 2010 . Until the mid-1990s, the $90 / 10$ percentile ratio remained more or less constant. This was true also for the equivalent measures of wage inequality in the lower and upper tails of the distribution, i.e., the 50/20 and $90 / 50$ percentile ratios, respectively. Since then, wage inequality has followed a markedly upward trend. In the mid-1980s, the earnings of workers in the ninth decile were approximately 2.5 times greater than the earnings of workers in the first decile. At the end of the observation period, the corresponding value was 3.5. Figure 6 indicates that the

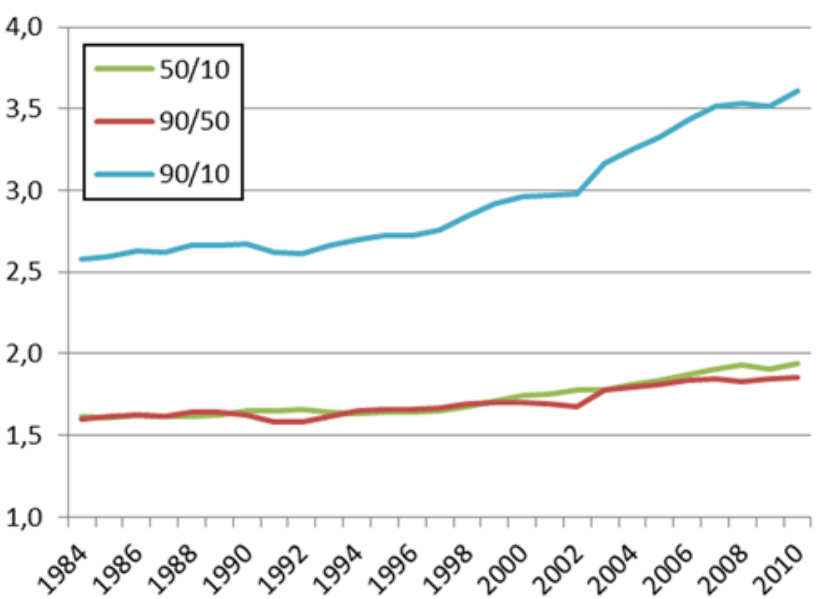

Fig. 6 Indicators of wage inequality among full-time workers aged 25-55 in West Germany, 1984-2010 (decile ratios). (Source: Own calculation with SIAB data)

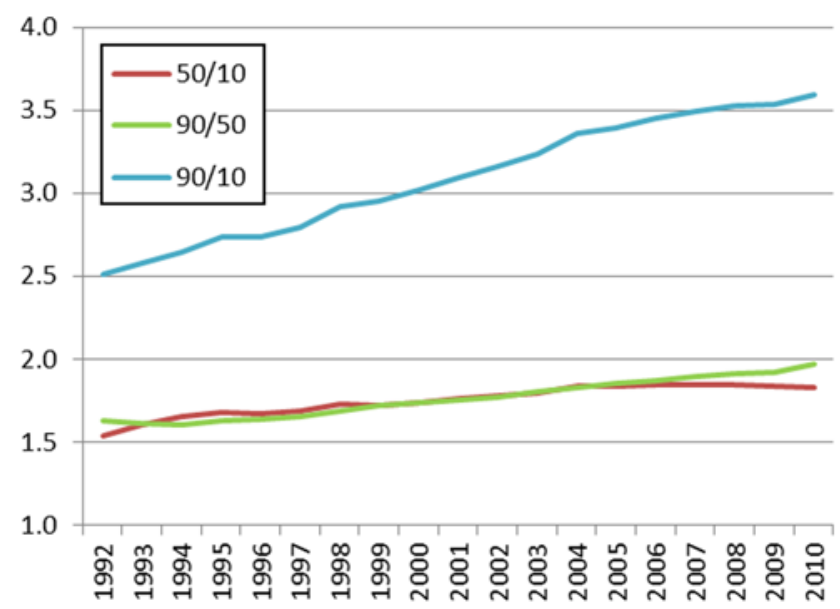

Fig. 7 Indicators of wage inequality among full-time workers aged 25-55 in East Germany, 1984-2010 (decile ratios). (Source: Own calculation with SIAB data)

increase in inequality in both tails of the distribution contributed to higher wage dispersion. The increases in the 50/10 and 90/50 percentile ratios were quite similar, although the changes in the low tail were slightly more pronounced after the labor market reforms.

Figure 7 indicates that wage inequality also increased among prime-age full-time workers in East Germany. Again, one can observe that this development is driven by higher decile ratios in the lower and upper tails of the distribution. Figure 8 compares the changes in wage dispersion in both parts of the country. It turns out that the increase in the extent and structure of wage inequality in East and West Germany during the post re-unification period is astonishingly similar. Furthermore, the decile ratios for both tails of the distribution are approximately equal. Although the wage 


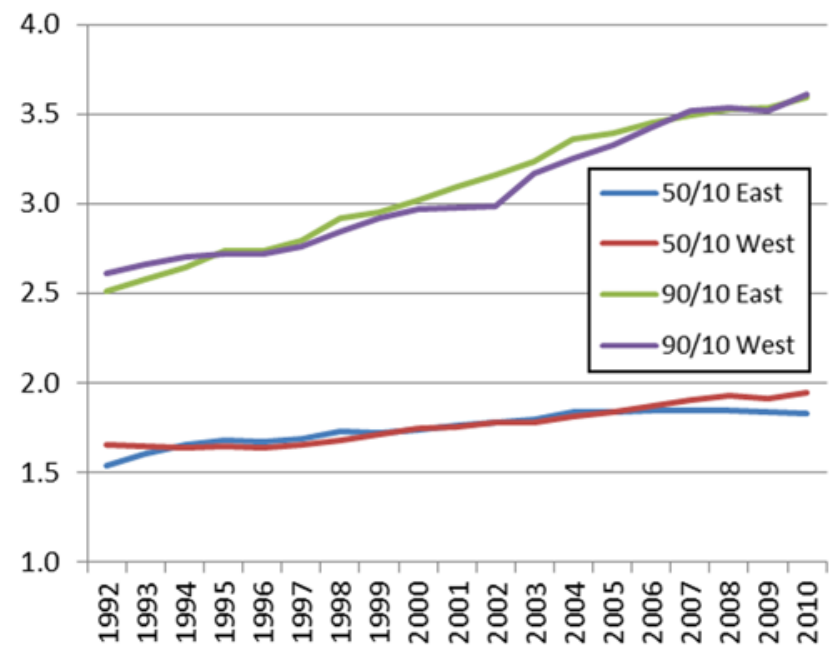

Fig. 8 Indicators of wage inequality among full-time workers aged 25-55 by region 1992-2010, (decile ratios). (Source: Own calculation with SIAB data)

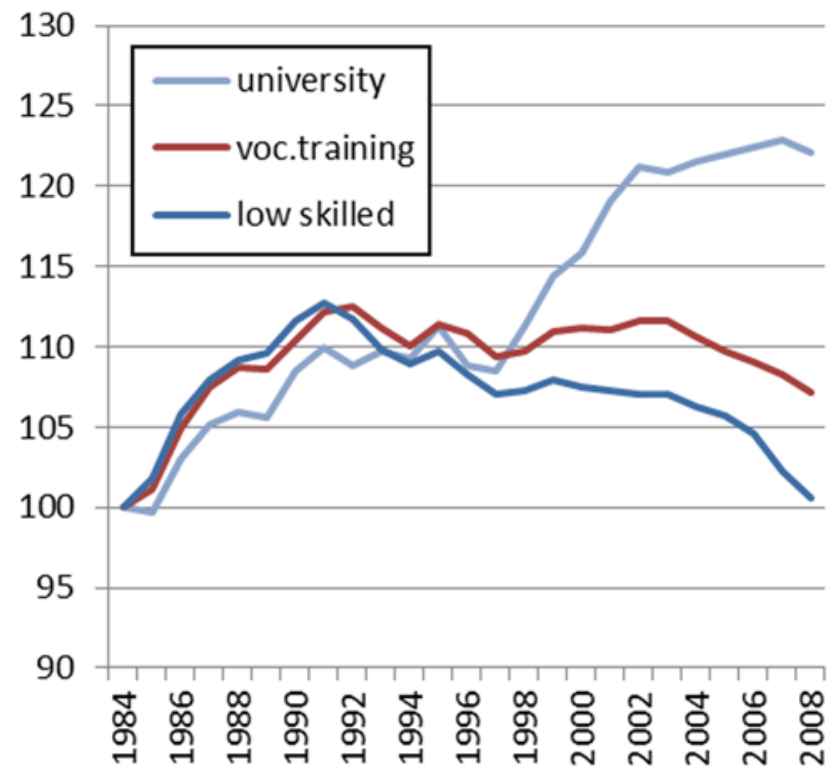

Fig. 9 Real wage index by qualification type for full-time male workers aged 40 in West Germany, 1984 to 2008. (Source: Own calculations using SIAB data)

level is still different in both parts of the country, it seems that wage inequality has more or less converged.

A further important aspect concerns the wage structure related to skill differentials. Figure 9 depicts the development of an index of real earnings for full-time male workers aged 40 in West Germany according to three skill levels (low skilled, workers with vocational training and university graduates). It turns out that until re-unification (1991), real wages were increasing among all skill groups. In the first half of the nineties, real wages were stagnating among all groups. Since the mid-nineties however, the development of

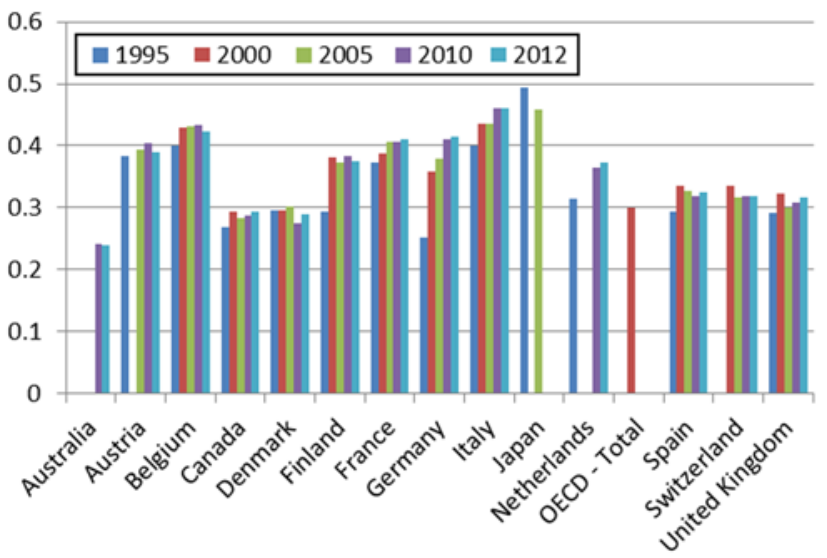

Fig. 10 Share of the labor force employed for at least 10 years by country for different years, in calendar days. (Source: Own calculation using the OECD database (European Labor Force Survey))

real earnings among the skill groups has clearly diverged. Whereas workers with a university degree experienced sharp increases in their real earnings, the earnings of low skilled workers declined. This is especially true after 2005. For one and a half decades after 1990, the real earnings of the intermediate skill group more or less stagnated, but then decreased as well. Hence, sizeable groups of workers suffered losses in real earnings, especially in the years after the labor market reforms. With stagnating or even declining real earnings among the majority of workers, unit labor costs have fallen considerably.

At the same time, the share of low-wage earners increased markedly. This is true for total employment as well as for subsamples divided by region (East/West) or gender. Figure 9 shows that this development had already started in the midnineties. The trend towards a higher share of low-pay employment has accelerated only to a certain extent since 2005 .

To sum up, it seems that the German economy has become much less egalitarian than it has been traditionally. The lowpay sector has risen dramatically, as noted by Rhein (2013). Almost a quarter of all employees received less than the low pay threshold of $9.54 €$ in 2010. According to Rhein (2013), Germany has moved from being a country with intermediate earnings inequality to belonging to the group with the greatest levels of inequality in Europe. If all employees are considered, the size of the low-pay sector even exceeds that of the United Kingdom.

\subsection{Changes in job stability}

As mentioned in Sect. 2, a basic element of the German model is a relatively long job tenure. Using OECD data mainly based on the European Labor Force Survey, I calculated the share of the labor force employed for at least 10 years for a number of countries. Figure 10 shows the results for 1995, 2000, 2005, 2010 and 2012. In a broad classifi- 


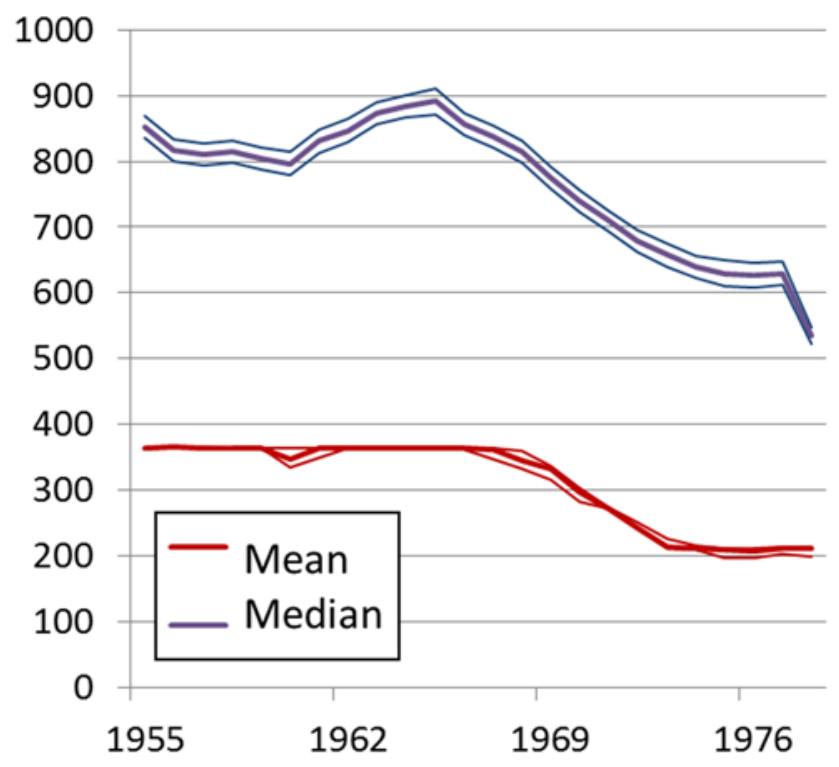

Fig. 11 Length of employment spells for different birth cohorts of workers below the Age of 30

cation, the countries can be divided into three groups: (i) short-tenure countries like Australia, Canada and Denmark; (ii) an intermediate group including Spain, Switzerland and the United Kingdom; (iii) and long-tenure countries like Japan, Italy, Belgium, the Netherlands and France. Note that the results for Germany in the 1990s and early 2000s are likely to be biased because German re-unification interrupted the careers of many East German workers. If this potential bias is taken into consideration, Germany clearly belongs to the high-tenure category of countries. In 2012, approximately $41 \%$ of German workers had held their job positions for at least 10 years. This is lower than the values found for Italy (46\%) and Belgium (42\%), but markedly higher than in Australia (24\%), Canada (28\%) or the United Kingdom (31\%). In the German case, there was an overall upward trend in the share of the workforce with a long tenure. Hence, there is no indication that labor market reforms changed the fact that the German model relies on a significant part of the workforce experiencing a high level of job stability. If anything, employment duration and tenure have increased, not decreased. A closer look at the empirical evidence shows, however, that this is not the case for all groups of workers. Especially for young workers in general and young low-skilled workers in particular, the average length of an employment spell has declined markedly.

Figure 11 shows Kaplan-Meier estimates for the length of employment spells of workers below the age of 30 belonging to different birth cohorts. The median spell length is rather stable until the birth cohort of 1965. Since then, this indicator of employment stability has declined substantially. While the median spell length was between 800 and 900 days among older cohorts, it declined to slightly above 600
Table 2 Share of standard employment contracts in total employment by age and skill groups (percentage)

\begin{tabular}{llllll}
\hline & 1991 & 2000 & 2013 & $2000 / 1991$ & $2013 / 2000$ \\
\hline Age & & & & & \\
$15-24$ & 56.0 & 35.8 & 30.5 & -36.1 & -14.8 \\
$25-49$ & 71.1 & 65.3 & 59.0 & -8.2 & -9.6 \\
50-64 & 67.6 & 61.2 & 57.5 & -9.5 & -6.0 \\
Skill level & & & & & \\
Low & 53.2 & 44.0 & 30.6 & -17.3 & -30.5 \\
Intermediate & 73.0 & 66.0 & 59.5 & -9.6 & -9.8 \\
High & 68.5 & 62.5 & 58.2 & -8.8 & -6.9 \\
\hline
\end{tabular}

Share of employees with permanent contracts and working hours $>31$ h/per week; source: Destatis (Mikrozensus)

days for the cohorts born in 1975 and later. This development corresponds to a decline of roughly one-third. It should be stressed that cohorts born in the mid-sixties reached the age of 30 in the mid-1990s. Hence, the trend towards a decline in job quality for young workers had already started well before the implementation of the labor market reforms. Note that the mean length of employment spells is below the median shown in Fig. 11. This indicates a lot of probability mass at very short spells.

The general finding of greater job instability among young workers is supported by a recent study of Rhein and Stüber (2014). They find that especially among low-skilled workers, the average length of an employment spell has decreased considerably. The authors also exclude the possibility that higher job instability is attributable to an increase in instances of voluntary job termination.

\subsection{Increase in non-standard employment}

A further change in the structure of the German labor market is related to the rising share of non-standard employment. Non-standard employment comprises part-time and minor employment as well as employment with all types of fixed-term contracts. It should be emphasized that not all forms of non-standard employment imply low-quality jobs. For example, part-time work might be voluntarily chosen for family reasons. The same applies to some fixed-term contracts when they correspond to the preferences of workers. In general, however, non-standard employment is more likely to be associated with low job quality.

Table 2 shows that standard employment follows a declining trend in the long run. For the youngest age group, the share of standard employment contracts almost halved from the beginning of the 1990s to the latest period. Looking at sub-periods reveals that the lion's share of the decline occurred in the 1990s. For prime-age employees (age 25-49), the shrinking share of standard employment accelerated slightly in the 2000 s, whereas this is not the case for older workers. Looking at the skill level, there is a clear 
indication that the increase in non-standard employment is highly concentrated among low-skilled workers. This might also be due to the de-regulation over the course of the labor market reforms.

Overall, one can conclude that the creeping process of erosion in standard employment was not initiated by the Agenda policy during the period from 2003 to 2005. However, some of the elements of the reform have favored this development.

\section{Discussion and conclusions}

Assessing labor market performance in general, it is fair to recognize the sizeable merits of the reform efforts. The "teutonic turnaround" has substantially contributed to the employment records and reductions in short- and long-term unemployment in the last 10 years. Moreover, the reform agenda was also relevant for the German "labor market miracle" during the Great Recession of 2008/2009. These statements are partly at odds with the conclusion of a widely recognized recent study:

The scale of the reforms is modest enough that they seem unlikely to have triggered the dramatic increase in competitiveness or the enormous drop in German unemployment or to have led Germany's labor market through the deep recession in 2008-2009. Further, while the focus of the reforms was on creating incentives for seeking employment, they did little to support the remarkable wage restraint witnessed since the mid-1990s, which is the key factor in explaining the gain in competitiveness (Dustmann et al. 2014, p. 184).

As I argued above, it is true that wage restraint and the increase in wage dispersion started well before the labor market reforms, approximately 1995 . It is also true that the substantial improvement in competitiveness of German exporters is closely linked to the relative decrease of Germany's unit labor costs vis-à-vis its trading partners, which was mainly due to this wage moderation. However, it is a severe misunderstanding to assess the scale of the reforms as "modest." The Hartz reforms, especially the merger between unemployment assistance and welfare, deeply changed the fundamental labor market institutions. What Dustmann et al. (2014) fail to explain is the precise temporal coincidence of the reform process and the obvious break in the unemployment trend, the change in the parameters of the matching function and the indicators of the behavior of workers and the unemployed. The change in competitiveness has been occurring gradually since the mid-1990s, but for 10 years or so, no successes were apparent in the labor market. Only after the end of the reform process in 2005 did the unemployment figures decrease by approximately $40 \%$ in 3 years. Although an empirical macroeconomic analysis of the situation does not allow for a causal inference to be made in the strict sense, it is very likely and highly plausible that the drastic reforms implemented under chancellor Schröder had first- rather than second-order effects on labor market performance. Yet it should be emphasized that the timing of the German labor market reforms was well-chosen because they occurred during a period of an expansionary world market. My reading of the facts is that the combination of the structural reforms with the external boom helped to over-come the most dangerous threat to the foundations of the German model, i.e., the increase in systemic unemployment. Although not all parts of the reform process were well designed, the Agenda policy sharpened awareness that the acceptance of various forms of flexibility for firms to cushion against external economic shocks is mutually advantageous to employers and employees. This relates to working time and working-time accounts as well as remuneration schemes. Especially in the export-oriented manufacturing sector, these new forms of flexibility improved responsiveness to market signals and reinforced the effects of the long period of wage moderation on international competitiveness. Hence, one salient feature of the German model - its export-orientation based on a strong manufacturing sector-was even strengthened by the effects of the reform.

The stress test of the reforms came with the Great Recession. The German economy passed this test in an impressive way. Flexibility within firms and strong labor relations based on the social partnership were the key to understanding the mechanisms responsible for what has been called the German labor market miracle. Despite a more than $5 \%$ drop in GDP, massive layoffs and a deep decrease in the employment rate were avoided. At the same time, the financial sustainability of the social security system was secured. The wide acceptance of working-time and wage flexibility during the crisis can hardly be understood without the behavioral changes brought about by the reforms.

Several salient features of the German model-like the dual training system, long-tenures of prime-age skilled workers or well-functioning social partnership-were not negatively affected by the reforms. In particular, the system of labor relations is still rather distinct from that of the Anglo-Saxon approach.

In the light of the presented evidence, the Hartz reforms did not destroy the German model. However, it has undergone transformations and there are aspects of these that could be seen as representing the creeping erosion of some of its cornerstones. It would therefore be wrong to sweep the challenges to the German model under the rug. These challenges relate to the decline in the importance of collective bargaining agreements, growing labor market segmentation 
and increase in wage inequality. It should again be emphasized that all these phenomena - although often attributed to the reforms - were not caused by the Agenda policy implemented under chancellor Schröder from 2003 to 2005. They are due to long-run trends that had already started in the 1990s or even before. At most, the labor market reforms have led to a certain acceleration of these erosion processes, such as the increase in atypical employment among certain groups.

The reform process might be blamed, however, for ignoring and not counter-acting the erosion of some of the fundamentals of the German model. This raises the question of whether there is some scope for the reform process to be rectified. In other words, we can ask whether the trends in segmentation and inequality can be reversed without jeopardizing the obvious employment-related successes of the reforms.

The main element of the German model that was allegedly weakened by the reforms is social cohesion and solidarity. Traditionally, the German economy ran successfully with a rather low level of earnings inequality. At the same time, at least the important group of trained workers enjoyed a comfortable social security network. Today, workers are in much greater danger of losing their social status within a quite short period of time. Given the regulatory framework in place after the reforms, they are much more pressed to accept unfavorable working conditions and low-paid jobs. Wage inequality has risen sharply. Furthermore, social permeability has decreased over the years. Among recent criticisms of the German system, the education inheritance (Bildungsvererbung) is of major concern. The job and income risks borne by specific groups, namely the young and the low skilled, also seem to be increasing.

Overall, this has favored segmentation tendencies in society. Insofar as segmentation leads to the erosion of social cohesion and solidarity, a cornerstone of the German model is affected. This should seriously be taken into account.

With respect to the struggle against inequality, there are two controversial positions in the discussion about Germany. The first position claims that the marked increase of the low-wage sector was necessary to place less-productive workers in jobs. This strategy was largely successful and explains the upward trend in the German employment rate in the last years. Put differently, the increase in inequality is not an unintended by-product of the reform process but is rather the "nature of the game." Any attempt to counteract this development comes at a significant cost in terms of lower employment and higher unemployment. In this view, strengthening egalitarianism would cost jobs.

In contrast, the second position is based on the assertion that the marked increase of the low-wage sector was not necessary to improve the labor market situation of the least advantaged. According to this view, inequality represents unintended "collateral damage" of the reform. The reform process was deficient insofar as it did not counteract this unintended outcome. As a consequence, measures to reduce the marked increase in inequality are indicated.

There is some truth to both positions. As I have argued elsewhere in more detail (see Möller (2014b)), inequality has also increased among those workers who were employed throughout. On the one hand, this result at least weakens the position that lower wages were fully necessary to bring lowproductivity workers into jobs, because some workers who were employed also suffered from lower wages. This result shows that there is likely something like "excess inequality", i.e., inequality that goes beyond a "healthy" level. This inequality is not related to productivity, but is caused more by market power and other market imperfections. On the other hand, the possibility that that wage flexibility was, to some extent, helpful in integrating "problem groups" into the labor market cannot be excluded.

In light of this discussion, is seems that what is necessary is not a reversal of the reform process but a further, prudent and gradual development of reforms. The segmentation and inequality issues have to be addressed without throwing the baby out with the bathwater, i.e., without jeopardizing the employment-related successes. Adequate measures should include all efforts to enhance qualification among the disadvantaged and the labor market integration of the long-term unemployed. The introduction of a statutory minimum wage on January 1, 2015, was helpful in mitigating the inequality trend, but possible disemployment effects should be monitored carefully.

To summarize, the German labor market reforms were a necessary painful cure to stop the harmful trend of increasing systemic unemployment. However, their negative side effects should not to be overlooked. Mitigating the damage that increasing segmentation has inflicted on the German model will pose an important challenge in the future.

\section{Kurzfassung}

Der Aufsatz untersucht zunächst die besonderen Eigenschaften des deutschen Modells als einer Spielart der Organisation von Wirtschaft und Gesellschaft, die sich vom angelsächsischen ebenso wie vom skandinavischen Modell deutlich abhebt. Die Charakteristika, die das Modell Deutschland bestimmen, umfassen eine Vielzahl von Dimensionen, die auch teilweise untereinander in Wechselbeziehung stehen. Das deutsche Modell lässt sich im Grundsatz als eine soziale Marktwirtschaft mit korporatistischen Ansätzen kennzeichnen. Die Finanzierung der Sozialversicherung beruht seit ihrer Einführung unter Bismarck wesentlich auf lohnabhängigen Abgaben. Die soziale Absicherung ist vergleichsweise großzügig, auch um Risiken auf externen Märkten abzufedern. Der aktiven Arbeitsmarktpolitik kommt eine verglei- 
chsweise wichtige Rolle zu. Die Arbeitsbeziehungen sind durch Sozialpartnerschaft geprägt, die-unterstützt durch geeignete Institutionen wie das Kurzarbeitergeld - eine hohe betriebsinterne Flexibilität unterstützt. Die Unternehmen sind auf eine exportorientierte diversifizierte Qualitätsproduktion ausgerichtet, die strategisch erfolgreich Nischen auf den Weltmärkten besetzt. Das duale Ausbildungssystem liefert die dazu notwendigen qualifizierten Fachkräfte. Das verarbeitende Gewerbe ist von höherer Bedeutung als in vergleichbaren Ländern. Die Lohnverhandlungen erfolgen auf mittlerer Ebene und sind an der Produktivitätsentwicklung auf aggregierter Ebene orientiert. Die Lohnverteilung ist vergleichsweise egalitär gestaltet. Die Unternehmensfinanzierung geschieht durch Hausbanken, die auch Schwächeperioden mittelfristig überbrücken helfen. Der Zugang zu Risikokapital ist schwerer als etwa in den angelsächsischen Ländern. Unternehmensnetzwerke und -kooperationen werden durch eine gut ausgebaute Infrastruktur unterstützt (z. B. das Verkehrs- und Rechtssystem).

Der Aufsatz argumentiert, dass das deutsche Modell seit den 1970er Jahren durch den sprunghaften Anstieg der Sockelarbeitslosigkeit zunehmend unter Druck geriet, da das Finanzierungssystem der Sozialversicherung nicht auf hohe Unterbeschäftigung eingestellt ist. Dieser Druck wurde durch die Finanzierungsbedarfe aufgrund der deutschen Wiedervereinigung noch substantiell erhöht. Um einen Kollaps des Systems zu vermeiden, waren deshalb tiefgreifende Arbeitsmarktreformen letztlich unvermeidlich, die eine Verbesserung der Beschäftigungssituation in den Fokus rückten. Die mit den Reformen verfolgte Politik des Forderns und Förderns erwies sich in Bezug auf die Beschäftigungsentwicklung und den Abbau von Arbeitslosigkeit als außerordentlich erfolgreich. Dabei spielten Verhaltensänderungen bei den Arbeitssuchenden ebenso eine Rolle wie die erhöhte Effizienz im Vermittlungsprozess und im Einsatz arbeitsmarktpolitischer Maßnahmen. Die positive Entwicklung wurde durch ein gutes Timing der Reformen, deren Ende in eine Periode starker weltwirtschaftlicher Expansion fiel, noch verstärkt. Durch den starken Rückgang der Unterbeschäftigung konnte die Finanzierung der sozialen Sicherungssysteme wieder auf eine verlässliche Basis gestellt und damit zentrale Elemente des deutschen Modells gerettet werden.

Allerdings sind gewisse Erosionserscheinungen des deutschen Modells zu konstatieren. So nimmt die Tarifabdeckung ab, während die Lohnungleichheit stark anwächst. Zugleich verstärken sich Segmentierungsphänomene am deutschen Arbeitsmarkt. Im Unterschied zu einem weit verbreiteten Vorurteil zeigen die empirischen Fakten aber, dass diese Erosionserscheinungen nicht durch die Hartz-Reformen verursacht wurden. Die empirischen Fakten belegen, dass den geschilderten Phänomenen Trends zugrunde liegen, die schon lange vor den Reformen einsetzen. So steigt die Lohnspreizung bereits seit etwa Mitte der 1990er Jahre und die Tarifabdeckung folgt einem langfristig sinkenden Trend. Andere Merkmale, wie etwa die Betriebszugehörigkeit im Haupterwerbsalter haben sich hingegen gegenüber früheren Zeiten kaum verändert. Die betriebsinterne Flexibilität hat sich durch Einführung neuer Institutionen wie den Arbeitszeitkonten gegenüber früheren Zeiten sogar erhöht. Den Härtetest der Großen Rezession in den Jahren 2008/2009 bestand der deutsche Arbeitsmarkt mit Bravour. Der Beschäftigungsstand konnte fast gehalten werden, obwohl der Einbruch im Bruttoinlandsprodukt weitaus stärker war als in früheren Krisen. Nachdem die Krise schnell überwunden war, zeigte sich wieder eine robuste Aufwärtsbewegung der Beschäftigung und-wenn auch verhaltener als in der Zeit unmittelbar nach den Reformen-ein weiterer Rückgang der Arbeitslosigkeit. Wesentliche Bestandteile des deutschen Modells wie die starke Betriebsbindung von qualifizierten Facharbeiter/innen, das duale Ausbildungssystem, die starke Exportorientierung sowie eine solide finanzierte Sozialversicherung sind durch die Reformen nicht angetastet worden. Das deutsche Modell ist somit keineswegs abgewickelt worden, sondern im Kern weiterhin sehr lebendig. Dennoch sollte die schleichenden Erosionserscheinungen durch wachsende Segmentation und Lohnungleichheit nicht verharmlost werden. Um der Devise Ludwig Erhards „Wohlstand für alle" zu ihrem Recht zu verhelfen, sind auch arbeitsmarktpolitisch einige Herausforderungen zu bewältigen. Erforderlich sind ausgewogene Maßnahmen, die nicht die Beschäftigungserfolge des bisherigen Reformprozesses wieder in Frage stellen. Der zum Jahresanfang eingeführte Mindestlohn von 8,50€ könnte dieses Kriterium erfüllen, auch wenn die abschließende Beurteilung seiner Beschäftigungswirkungen zum jetzigen Zeitpunkt noch nicht möglich ist. Zur Stärkung des deutschen Modells sind auch Konzepte zur Abmilderung der Segmentierungserscheinungen erforderlich. Hierzu bedarf es arbeitsmarktpolitischer Konzepte, die Langzeitarbeitslosigkeit wirksam bekämpfen und schwächere Gruppen am Arbeitsmarkt wie die Geringqualifizierten noch stärker in den Fokus nehmen, die in den letzten zwei oder drei Dekaden zu den Verlierern am Arbeitsmarkt gehört haben. Auch die sich im Trend abzeichnende größere Instabilität der Beschäftigungsverhältnisse Jugendlicher und junger Erwachsener ist im Auge zu behalten.

\section{References}

Abraham, C.G., Houseman, S.N.: Labor adjustment under different institutional structures: A case study of Germany and the United States. In Buttler, F., Franz, W., Schettkat, R., Soskice, D. (eds.): Institutional Frameworks and Labor Market Performance: Comparative Views on the U.S. and German Economies, pp. 285-315. (1995) 
Albert, M.: Capitalism vs. Capitalism. How America's Obsession With Individual Achievement And Short-Term Profit Has Led It To The Brink Of Collapse. Four Walls Eight Windows, New York (1993)

Blanchard, O.J., Giavazzi, F.: Macroeconomic effects of regulation and deregulation in goods and labor markets. Quarterly J. Econ. 118(3), Available online at 879-908 (2003)

Blanchard, O.J., Summers, L.H.: Hysteresis in Unemployment. In International labour review (1987)

Boyer, R.: What is the future for codetermination and corporate governance in Germany? In: Beckert, J., Ebbinghaus, B., Hassel, A., Philip, M. (eds.) Transformationen des Kapitalismus. Festschrift für Wolfgang Streeck zum sechzigsten Geburtstag. With assistance of Wolfgang Streeck, pp. 135-157. Campus Verl, Frankfurt (2006) (Schriften aus dem Max-Planck-Institut für Gesellschaftsforschung Band 57)

Bruno, M., Sachs, J.D.: Economics of Worldwide Stagflation. Harvard University Press, Cambridge (1985)

Burda, M.C.: Corporatism, labor unions and the safety net. Eur. Econ. Rev. 41(3-5), 635-646 (1997). doi:10.1016/ S0014-2921(97)00026-3

Burda, M.C., Hunt, J.: What explains the German labor market miracle in the great recession? Brookings Papers on Economic Activity 42 (1), pp. 273-335. Available online at http://ideas.repec.org/a/bin/ bpeajo/v42y2011i2011-01p273-335.html (2011)

Burda, M.C., Sachs, J.D.: Institutional Aspects of High Unemployment in the Federal Republic of Germany. National Bureau of Economic Research Cambridge, Mass., USA (NBER working paper series, 2241) (1987)

Burda, M.C., Sachs, J.D.: Assessing high unemployment in West Germany. World Econ. 11(4), 543-563 (1988). doi:10.1111/j.1467-9701.1988.tb00148.x

Calmfors, L.: Centralisation of wage bargaining and macroeconomic performance. A survey. OECD Economic Studies 21 (Winter), 161-191 (1993)

Calmfors, L., Driffill, J.: Bargaining structure, corporatism and macroeconomic performance. In Economic Policy3(1), 13-61. Available online at http://search.ebscohost.com/login.aspx?direct=true \& db= buh\&AN=15154518\&site $=$ ehost-live (1988)

Card, D., Heining, J., Kline, P.: Workplace heterogeneity and the rise of West German wage inequality. Quarterly J. Econ. 128(3), 9671015 (2013)

Crouch, C.: Diversity in employment patterns in North-West Europe. A regional and sectoral approach. In: Beckert, J., Ebbinghaus, B., Hassel, A., Philip, M. (eds.) Transformationen des Kapitalismus. Festschrift für Wolfgang Streeck zum sechzigsten Geburtstag. With assistance of Wolfgang Streeck, pp. 159-179. Campus Verl, Frankfurt (2006) (Schriften aus dem Max-Planck-Institut für Gesellschaftsforschung Band 57)

Deutscher Bundestag: Stenographischer Bericht. Berlin (Plenarprotokoll, 15/32) (2003)

Driffill, J.: The Centralization of Wage Bargaining. Revisited: What Have we Learnt?. J. Common Market Stud. 44(4), 731-756 (2006)

Dustmann, C., Ludsteck, J., Schönberg, U.: Revisiting the German wage structure. Quarterly J. Econ. 124(2), 843-881 (2009)

Dustmann, C., Fitzenberger, B., Schönberg, U., Spitz-Oener, A.: From sick man of Europe to economic superstar: Germany's resurgent economy. J. Econ. Perspect. 28(1), 167-188 (2014). DOI:10.1257/ jep.28.1.167

Eichengreen, B.: The German economy: Be careful what you ask for. http://www.eurointelligence.com/news-details/article/the-germaneconomy-be-careful-what-you-ask-for.html?cHash $=050 \mathrm{f} 9 \mathrm{ab} 081 \mathrm{c}$ 28f7499b4f565d2b00754. Accessed 1 Mai 2014 (2007)

Esping-Andersen, G.: The Three Worlds of Welfare Capitalism. Princeton University Press, Princeton (1990)
Fahr, R., Sunde, U.: Did the hartz reforms speed-up the matching process? A macro-evaluation using empirical matching functions. German Econ. Rev. 10(3), 284-316 (2009). doi:10.1111/j.1468-0475.2008.00457.x

Freeman, R.B.: Single-peaked versus diversified capitalism. The relation between economic institutions and outcomes. In: Drèze, J. (ed.) Advances in Macroeconomic Theory, vol. 2001, pp. 139 -170. Palgrave, Basingstoke (2001)

Freeman, R.B., Schettkat, R.: Marketization of production and the U.S.-Europe employment gap. Oxf. Bull. Econ. Stat. 63(0), 647$670(2001)$

Glyn, A., Möller, J., Salverda, W., Schmitt, J., Sollogoub, M.: Employment differences in distribution: Wages, productivity and demand. In: Gregory, M., Salverda, W., Schettkat, R. (eds.) Services and Employment. Explaining the U.S.-European gap, pp. 141-175. Princeton University Press, Princeton (2007)

Hall, P.A., Soskice, D.W. (eds.): Varieties of Capitalism: The Institutional Foundations of Comparative Advantage, University Press, 2001. Oxford University Press, Oxford (2001a)

Hall, P.A., Soskice, D.W.: An introduction to varieties of capitalism. In: Hall, P., Soskice, D.W. (eds.) Varieties of Capitalism: The Institutional Foundations of Comparative Advantage, University Press, 2001, vol. 1, pp. 1-68. Oxford University Press, Oxford (2001b)

Hilferding, R.: Das Finanzkapital. Wien: Marx-Studien (Blätter zur Theorie und Politik des wissenschaftlichen Sozialismus., 3) (1910)

IAB, Institut für Arbeitsmarkt- und Berufsforschung: Tarifbindung der Beschäftigten. Available online at http://doku.iab.de/aktuell/2014/ Tarifbindung_2013.pdf (2014). Accessed 1 July 2015

Kenworthy, L.: Corporatism and Unemployment in the 1980s and 1990s. American Sociol. Rev. 67(3), 367-388 (2002)

Kenworthy, L.: Germany's employment problem in comparative perspective. In: Beckert, J., Ebbinghaus, B., Hassel, A., Philip, M. (eds.) Transformationen des Kapitalismus. Festschrift für Wolfgang Streeck zum sechzigsten Geburtstag. With assistance of Wolfgang Streeck, pp. 37-59. Campus Verl, Frankfurt (2006) (Schriften aus dem Max-Planck-Institut für Gesellschaftsforschung Band 57)

Klinger, S., Rothe, T.: The impact of labour market reforms and economic performance on the matching of the short-term and the longterm unemployed. Scott. J. Political Econ. 59(1), 90-114 (2012)

Layard, R., Nickell, S.J., Jackman, R.: Unemployment. Macroeconomic performance and the labour market. Oxford [England]. Oxford University Press, New York (1991)

Möller, J.: The German labor market response in the world recession-De-mystifying a miracle. ZAF. 42(4), 325-336 (2010). doi:10.1007/s12651-009-0026-6

Möller, J.: Hartz IV and the consequences. Did the labour market reforms destroy the german model? In: Collignon, S., Esposito, P. (eds.) Competitiveness in the European economy, pp. 129-142. Routledge (Routledge studies in the European economy), London (2014a)

Möller, J.: In the Aftermath of the German Labor Market Reforms. Is there a Qualitative-Quantitative Trade-off? Nürnberg (Unpublished Working Paper) (2014b)

Möller, J.: Prosperity, sustainable employment and social justice: Challenges for the German labor market in the twenty-first century. In International Journal for Educational and Vocational Guidance. doi:10.1007/s10775-013-9259-6 (2014c)

Rhein, T.: Erwerbseinkommen: Deutsche Geringverdiener im europäischen Vergleich. In IAB-Kurzbericht Nürnberg (15/2013) (2013):

Rhein, T., Stüber, H.: Beschäftigungsdauer im Zeitvergleich: Bei Jüngeren ist die Stabilität der Beschäftigung gesunken. In IAB-Kurzbericht, (03/2014) (2014) 
Schnabel, C.: Determinants of Union Membership in 18 EU Countries. Evidence from Micro Data, 2002/03. http://hdl.handle. net/10419/23772 (2005)

Sperling, G.: The Renaissance of American Manufacturing (Remarks at the Conference on the Renaissance of American Manufacturing, March 27, 2012.). http://www.brookings.edu/ /media/ events/2013/7/25-manufacturing/the-case-for-a-manufacturingrenaissancegene-sperling7252013finalp.pdf. Accessed 24 Jan. 2015 (2012)

Stops, M.: Revisiting German labour market reform effects. A panel data analysis for occupational labour markets. Institut für Arbeitsmarkt- und Berufsforschung (IAB) (IAB Discussion Paper, 2 (2015)

Streeck, W.: Social Institutions and Economic Performance. Studies of Industrial Relations in Advanced Industrialized Countries. Sage Publ, London (1992)

Streeck, W.: German capitalism: Does it exist? Can it survive? MaxPlanck-Institut für Gesellschaftsforschung (95/5) (1995)

Streeck, W.: German capitalism: Does it exist? Can it survive? New Political Econ. 2(2), 237-256 (1997)

Streeck, W.: Nach dem Korporatismus: Neue Eliten, neue Konflikte (MPIfG working paper, 05/4). http://hdl.handle.net/10419/44269. Accessed 24 Feb. 2014 (2005)

Thelen, K.A.: Varieties of capitalism: Trajectories of liberalization and the new politics of social solidarity. Annu. Rev. Political Sci. 15, 137-159 (2012)
Thelen, K.A., van Wijnbergen, C.: The paradox of globalization: Labor relations in Germany and beyond. Comp. Political Stud. 36(8), 859-880 (2003). doi:10.1177/0010414003256111

Visser, J.: Two cheers for corporatism, One for the market. Industrial relations, wage moderation and job growth in the Netherlands. British J. Industrial Relat. 36(2), 269-292 (1998)

Vitols, S.: Das „deutsche Modell“ in der politischen Ökonomie. In: Berghahn, V.R., Vitols, S. (eds.) Gibt es einen deutschen Kapitalismus? Tradition und globale Perspektiven der sozialen Marktwirtschaft, 1. Aufl, pp. 44-59. Campus Verlag, Frankfurt a. M. (2006)

Joachim Möller, Since 2007 Joachim Möller is Director of the Institute for Employment Research of the Federal Employment Agency (Institut für Arbeitsmarkt- und Berufsforschung (IAB), Nuremberg/ Germany. He studied economics and philosophy at the Universities of Tübingen, Strasbourg and Konstanz. Since 1996 he holds a chair of economics at the University of Regensburg/Germany. His interests include empirical macroeconomics, regional development and regional labor markets. In June 2008 he has been awarded an honorary doctorate by the Leuphana University, Lüneburg. 